\title{
Technical and Economic Analysis of The Use of Solar Panel and Wind Turbine as Source of Electrical Power to Fulfill The Need for Lighting in The 2000GT Pioneer Ship
}

\author{
Hutrizain Claudio Raypa Saragih ${ }^{a, *}$, Agoes Achmad Masroeri ${ }^{\mathrm{b}}$ and Juniarko Prananda \\ Department of Marine Engineering, Institut Teknologi Sepuluh Nopember, Surabaya, Indonesia \\ a.hutri17@gmail.com, b.agoesrngkt@gmail.com,c.juniarko.prananda@gmail.com \\ *hutri17@gmail.com
}

Keywords: $\quad$ Solar Panel, Wind Turbine, Pioneer Ship, Break-Even Point (BEP).

\begin{abstract}
Pioneer ship are ships made to connect harbors that are not yet economically and viable. In daily operation, ships depend heavily on the use of fuel oil to run main engines, generators, emergency generators, etc. Fuel consumption is high while the operational of pioneer ship is not yet economically and viable. This paper proposes the utilization of solar panel and wind turbine as an alternatives energy to fulfil the need of lighting in roro ferry 2000 GT. This research clearly shows that the solar panels and wind turbines obtained are $55.68 \mathrm{KW}$ and $17.48 \mathrm{KW}$ total power respectively. In terms of economics, the utilization of solar panels and wind turbines save fuel consumption in 2000 GT roro ferry as much as $17.53 \%$ per year. The economic feasibility analysis is conducted by considering operational, and maintenance costs of the conventional system and hybrid system. It is clearly shown that the break-even point value is obtained after 3 years and 10 months after operation of system.
\end{abstract}

\section{Introduction}

Pioneer vessels are a central government project to serve isolated region because it has not yet economically feasible. In daily cruises, general pioneer vessels use fossil fuels to drive the main engine and drive the generator to supply the ship's electrical needs. As pioneering vessel, it is necessary to make savings to minimize operational costs such as the purchase of fuel oil and ensure ticket prices remain cheap.

One way to overcome dependence on fossil fuels and to make operational cost savings is to use renewable. The renewable energy can be used to supply the ship's electrical needs such as lighting, navigation equipment, and pumps. The renewable energy that can be used to be a source of electrical energy in the ship is wind energy and solar energy.

In this paper, the issues that will be discussed are the analysis of the use of wind turbines and solar panels as a source of electrical energy for lighting, optimization of solar panel selection and 
wind turbine of the most optimum, and analysis of the economics of utilization of solar panels and wind turbines to meet the needs of lighting on a 2000GT pioneer ship.

\section{Method}

The method that will be used to solve the above problem is used calculation and analysis method. The research flowchart is shown in Figure 1.

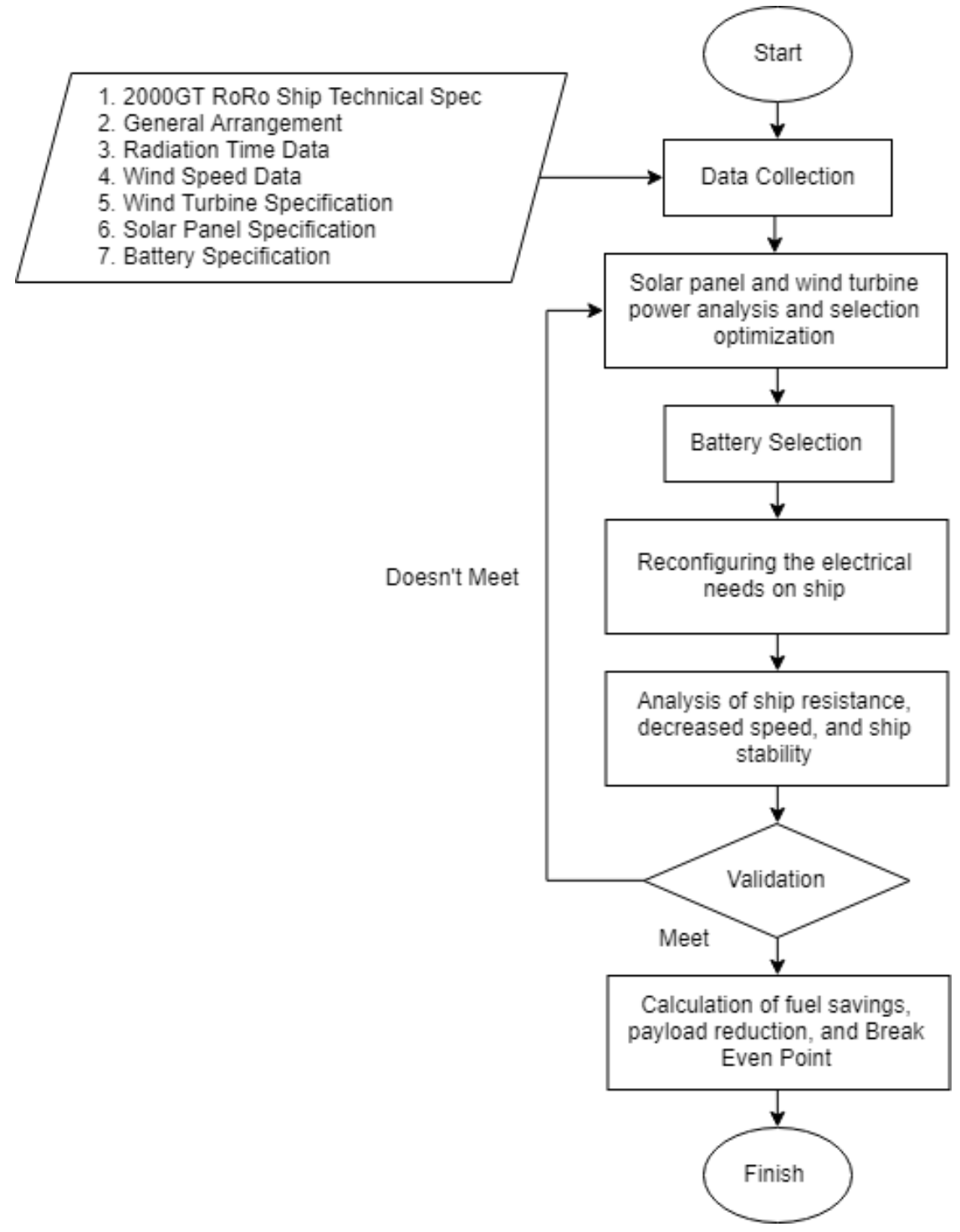

Figure 1: Research Flowchart

In the technical analysis phase, calculate the solar energy potential and wind energy potential that can be produced and selection optimization of solar panels and wind turbines. As validation, reconfigure the ship electrical system, analyze the ship resistance, decreased vessel speed, and ship stability. And in the economic phase, calculate the payload reduction, fuel savings, and break even point.

The principal dimension of pioneer ship with the type of roro ferry are:
- Length Overall
$: 80,22$
$\mathrm{M}$
- Length Between Perpendiculars : :72,00 M 
- Breadth

- Height

- Draft

- Service Speed
$: 15,20$

$: 5,10$

$: 3,60$

$: 15,00$
$\mathrm{M}$

$\mathrm{M}$

M

Knots

\section{Result And Discussion}

\subsection{Lighting Lamps Load Analysis}

Total load of lighting of the hull compartment, vehicle deck, passenger deck 01, passenger deck 02, total navigation load and total navigation light are $5.747 \mathrm{~kW}, 4,388 \mathrm{~kW}, 9,221 \mathrm{~kW}, 30.48 \mathrm{~kW}$, $4,643 \mathrm{~kW}$ and $5.5 \mathrm{~kW}$ respectively. So the total load of lighting on the $2000 \mathrm{GT}$ pioneer vessel is $59.977 \mathrm{~kW}$.

\subsection{Radiation Time and Wind Speed Analysis}

For the route from Lamongan (Paciran) to Bahaur through the Java Sea we can obtain data from the Meteorology Climatology and Geophysics Agency (BMKG) as measured from the Meteorological Station of Sangkapura (WMO ID 96925). Radiation time data is taken within the last 12 months which can be seen in Table 1 below and average wind speed data is taken within the last 12 months which can be seen in Table 2 below.

Table 1: Radiation Time Data

\begin{tabular}{|c|l|c|}
\hline No & \multicolumn{1}{|c|}{ Month } & Radiation Time (Hours) \\
\hline 1 & October & 3,36 \\
\hline 2 & November & 4,95 \\
\hline 3 & December & 2,22 \\
\hline 4 & January & 4,09 \\
\hline 5 & February & 3,37 \\
\hline 6 & March & 5,32 \\
\hline 7 & April & 6,56 \\
\hline 8 & May & 6,31 \\
\hline 9 & June & 6,12 \\
\hline 10 & July & 6,45 \\
\hline 11 & August & 8,78 \\
\hline 12 & September & 8,67 \\
\hline 13 & October & 8,24 \\
\hline \multicolumn{2}{|c|}{ Average Radiation Time (Hours) } & 5,82 \\
\hline
\end{tabular}


Table 2: Wind Speed data

\begin{tabular}{|c|l|c|}
\hline No & \multicolumn{1}{|c|}{ Month } & Wind Speed (Knots) \\
\hline 1 & October & 3,50 \\
\hline 2 & November & 3,53 \\
\hline 3 & December & 5,74 \\
\hline 4 & January & 5,77 \\
\hline 5 & February & 5,64 \\
\hline 6 & March & 4,57 \\
\hline 7 & April & 3,77 \\
\hline 8 & May & 4,86 \\
\hline 9 & June & 5,30 \\
\hline 10 & July & 5,58 \\
\hline 11 & August & 5,55 \\
\hline 12 & September & 5,67 \\
\hline 13 & October & 4,14 \\
\hline \multicolumn{2}{|c|}{ Average Wind Speed (Knots) } & 4,89 \\
\hline
\end{tabular}

\subsection{Optimization of Solar Panel Selection}

Optimization is done by choosing the most appropriate solar panel based on quantity, total power, total weight, power per area, and total price to use in each designated placement area.

Table 3 and Table 4 show the results of solar panel power calculations and optimization results applied to the navigation deck. Table 5 and Table 6 show the results of solar panel power calculations and optimization results applied to awning navigation deck. Table 7 and Table 8 show the results of solar panel power calculations and optimization results applied to awning top deck. From the optimization results, solar panels used in navigation decks, awnings navigation decks, and awnings top decks are SunPower E20-435-COM.

Table 3: Optimization of solar panels on navigation deck

\begin{tabular}{|c|c|c|c|c|c|c|}
\hline No & $\begin{array}{c}\text { Nominal Power } \\
(\mathbf{W})\end{array}$ & $\begin{array}{c}\text { Power } \\
(\mathbf{k W})\end{array}$ & $\begin{array}{c}\text { Power / Area } \\
\left(\mathbf{W} / \mathbf{m}^{\mathbf{2}}\right)\end{array}$ & Mass $(\mathbf{K g})$ & Total & $\begin{array}{c}\text { Price } \\
(\mathbf{U S D})\end{array}$ \\
\hline 1 & 435 & 27,84 & 151,12 & 1625,6 & 64 & 26.880 \\
\hline 2 & 345 & 31,74 & 172,29 & 1711,20 & 92 & 41.216 \\
\hline 3 & 320 & 25,28 & 137,22 & 2172,50 & 79 & 18.170 \\
\hline
\end{tabular}

Table 4: Result of Optimization of Solar Panels on Navigation Deck

\begin{tabular}{|c|c|c|c|c|c|c|}
\hline No & $\begin{array}{c}\text { Nominal Power } \\
(\mathbf{W})\end{array}$ & Power & Power / Area & Mass & Total & Price \\
\hline 1 & 435 & OK & OK & OK & OK & OK \\
\hline 2 & 345 & OK & OK & OK & $\mathrm{X}$ & $\mathrm{X}$ \\
\hline 3 & 320 & $\mathrm{X}$ & $\mathrm{X}$ & $\mathrm{X}$ & $\mathrm{OK}$ & $\mathrm{OK}$ \\
\hline
\end{tabular}


Table 5: Optimization of Solar Panels on Awning Navigation Deck

\begin{tabular}{|c|c|c|c|c|c|c|}
\hline No & $\begin{array}{c}\text { Nominal } \\
\text { Power }(\mathbf{W})\end{array}$ & $\begin{array}{c}\text { Power } \\
(\mathbf{k W})\end{array}$ & $\begin{array}{c}\text { Power / Area } \\
(\mathbf{W} / \mathbf{m} \mathbf{2})\end{array}$ & Mass $(\mathbf{K g})$ & Total & Price (USD) \\
\hline 1 & 435 & 8,7 & 136,6588 & 508 & 20 & USD 8.400 \\
\hline 2 & 345 & 8,97 & 140,9 & 483,6 & 26 & USD 11.648 \\
\hline 3 & 320 & 8,32 & 130,69 & 715,00 & 26 & USD 5.980 \\
\hline
\end{tabular}

Table 6: Result of Optimization of Solar Panels on Awning Navigation Deck

\begin{tabular}{|c|c|c|c|c|c|c|}
\hline No & $\begin{array}{c}\text { Nominal Power } \\
(\mathbf{W})\end{array}$ & Power & Power / Area & Mass & Total & Price \\
\hline 1 & 435 & OK & OK & OK & OK & OK \\
\hline 2 & 345 & OK & X & OK & OK & X \\
\hline 3 & 320 & OK & X & X & OK & OK \\
\hline
\end{tabular}

Table 7: Optimization of Solar Panels on Awning Top Deck

\begin{tabular}{|c|c|c|c|c|c|c|}
\hline No & $\begin{array}{c}\text { Nominal } \\
\text { Power }(\mathbf{W})\end{array}$ & $\begin{array}{c}\text { Power } \\
(\mathbf{k W})\end{array}$ & $\begin{array}{c}\text { Power / Area } \\
(\mathbf{W} / \mathbf{m} \mathbf{2})\end{array}$ & Mass $(\mathbf{K g})$ & Total & Price (USD) \\
\hline 1 & 435 & 17,40 & 156,60 & 1016,00 & 40 & USD 16.800 \\
\hline 2 & 345 & 8,97 & 140,90 & 483,60 & 26 & USD 11.648 \\
\hline 3 & 320 & 12,80 & 115,20 & 1100,00 & 40 & USD 9.200 \\
\hline
\end{tabular}

Table 8: Result of Optimization of Solar Panels on Awning Top Deck

\begin{tabular}{|c|c|c|c|c|c|c|}
\hline No & $\begin{array}{c}\text { Nominal Power } \\
(\mathbf{W})\end{array}$ & Power & Power / Area & Mass & Total & Price \\
\hline 1 & 435 & OK & OK & OK & OK & OK \\
\hline 2 & 345 & OK & OK & OK & X & X \\
\hline 3 & 320 & X & X & OK & OK & OK \\
\hline
\end{tabular}

\subsection{Optimization of Wind Turbine Selection}

Optimization of wind turbine selection is done by making scenarios of wind turbine placement that allows based on the area that has been determined. This placement scheme is based on the most likely placement of wind turbines that can be applied and then analyze and select the most optimum scenario.

In this optimization, 7 scenarios are made by utilizing the 5 specifications of wind turbines that have been analyzed in the previous stage. Table 9 shows the optimization results for each selected scenario. From the results of optimization, it is concluded that the wind turbine used to be applied is scenario 7 with 2 types of solar panels namely Aeolos V 3KW and Aeolos V 10KW. Figure 2 shows the selected wind turbine placement scenarios [1][3][7]. 
Table 9: Result of Optimization of Wind Turbine

\begin{tabular}{|c|c|c|c|c|}
\hline Scenario & Actual Power & Mass & Power / Mass & Price \\
\hline 1 & $\mathrm{X}$ & $\mathrm{OK}$ & $\mathrm{OK}$ & $\mathrm{OK}$ \\
\hline 2 & $\mathrm{X}$ & $\mathrm{X}$ & $\mathrm{X}$ & $\mathrm{X}$ \\
\hline 3 & $\mathrm{X}$ & $\mathrm{OK}$ & $\mathrm{OK}$ & $\mathrm{OK}$ \\
\hline 4 & $\mathrm{OK}$ & $\mathrm{OK}$ & $\mathrm{OK}$ & $\mathrm{X}$ \\
\hline 5 & $\mathrm{OK}$ & $\mathrm{X}$ & $\mathrm{X}$ & $\mathrm{X}$ \\
\hline 6 & $\mathrm{OK}$ & $\mathrm{OK}$ & $\mathrm{X}$ & $\mathrm{X}$ \\
\hline 7 & $\mathrm{OK}$ & $\mathrm{OK}$ & $\mathrm{OK}$ & $\mathrm{OK}$ \\
\hline
\end{tabular}

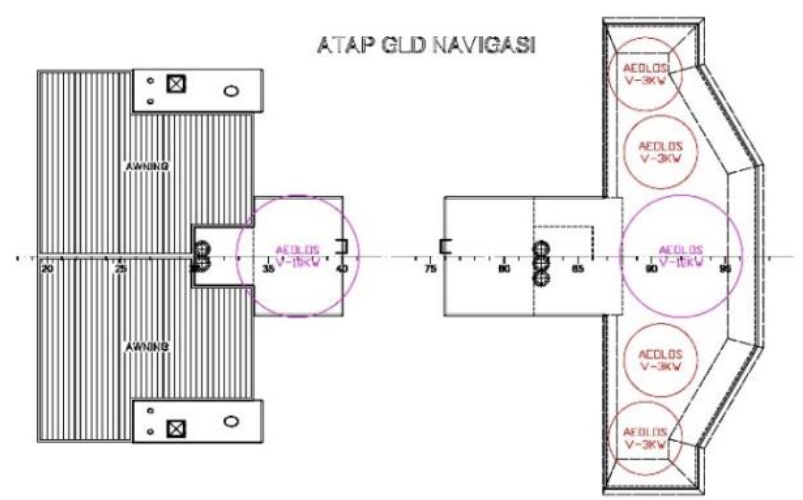

Figure 2. Position of Wind Turbine Installation

\subsection{Lighting Lamps Peak Load Calculation}

To manage the use of power generated by solar panels and wind turbines, it is necessary to calculate the total peak load of lights every hour as shown in Figure 3 and the result of power management shown in Figure 4.

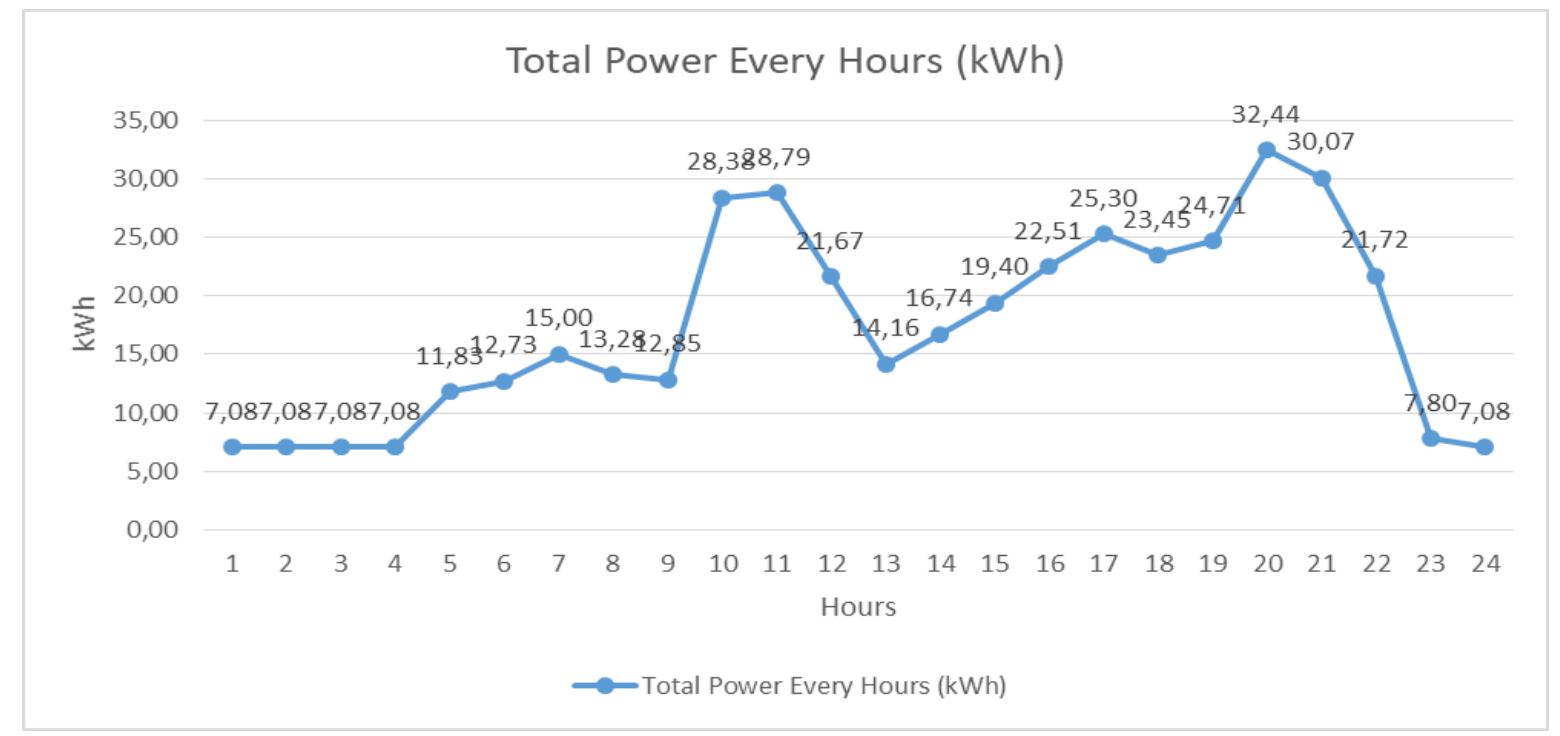

Figure 3. Lighting Load on Every Hour 


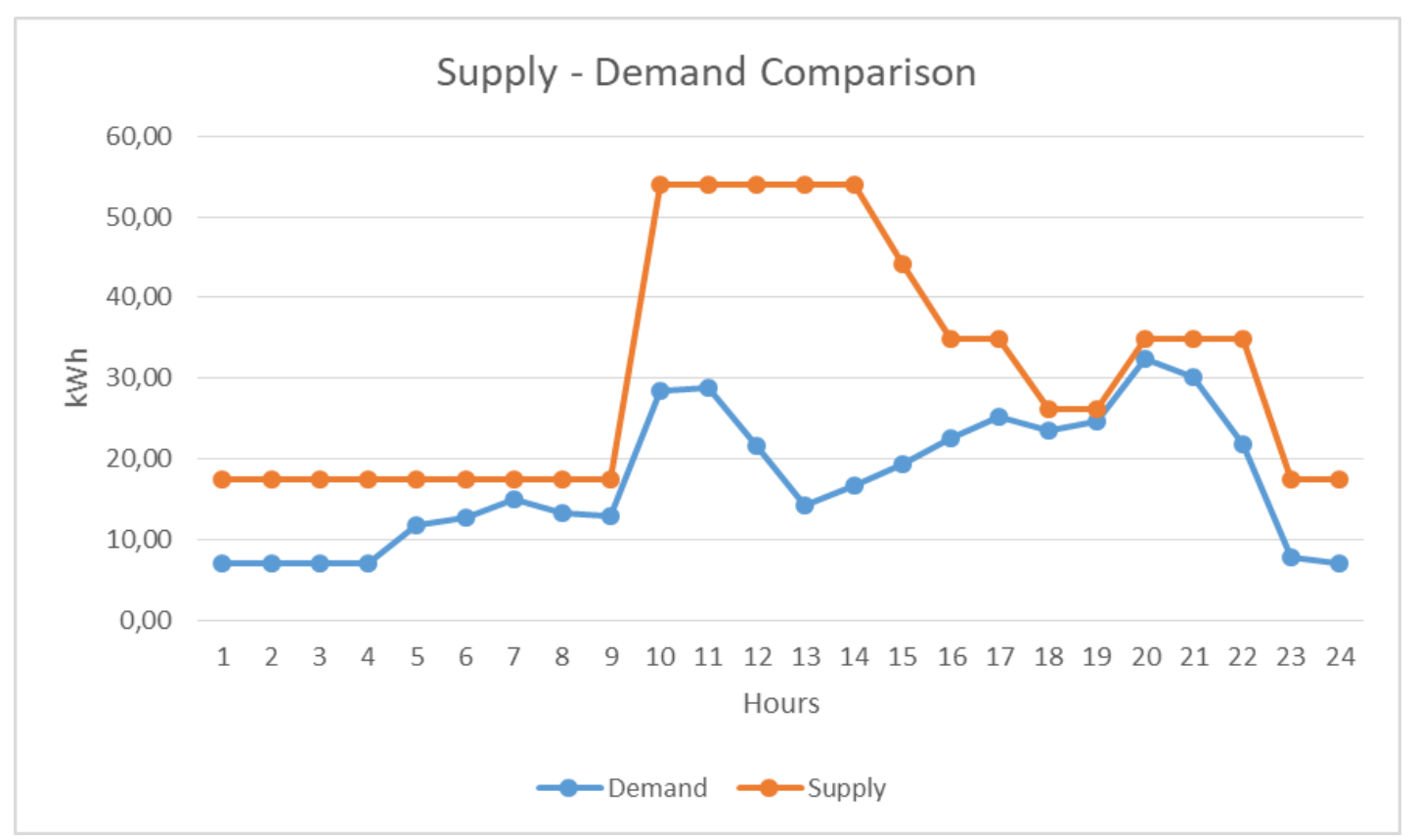

Figure 4. Comparison of Supply-Demand Power

\subsection{Reconfiguring Ship Electrical System}

The reconfiguration of the electrical system is done because of the addition of solar panels and wind turbines to supply the needs for lightings on the ship so we can reduce the amount of power that must be provided by the main generator of the ship. In reconfiguring the electrical system, scenarios are performed with trial \& error methods so it is discovered when the power generated by wind turbines and solar panels is stored and when the power generated is used to supply the lightings requirements on the ship. Based on the reconfiguration results of the electrical system on the 2000 GT Pioneer ship, the power requirements to be supplied by the ship's main generator can be reduced by $59.98 \mathrm{~kW}$.

\subsection{Calculation of Battery Needed}

In the design of this system, it needs battery to store electrical energy generated by solar panels and wind turbines. The batteries will be used to supply the electrical load requirements when they will be used in accordance with the results of reconfiguration scenarios of electrical systems on the ship. The power from the battery is planned to be use at $4 \mathrm{pm}-10 \mathrm{pm}$. In planning this battery requirement, also done a calculation of power difference between supply and demand so that can be saved and used when needed as a power reserve.

From the calculation results, the battery that chooses to store the power from a wind turbine and the solar panel is using AGM Type battery with specification $12 \mathrm{~V}$ and 375Ah. The number of battery needed to store wind turbine power is 68 unit and number of battery needed to store solar power is 52 unit [2][5].

\subsection{Ship Resistance, Speed, and Stability Analysis}

The simulation to know the wind resistance owned by both wind turbine using CFD software that serves to check the total force received by a wind turbine. The simulation results of $3 \mathrm{KW}$ wind 
turbine has wind resistance of 63.194359 N. Simulation results of $10 \mathrm{KW}$ wind turbine has wind resistance of $875.8197 \mathrm{~N}$ [4].

To analyze the prisoners possessed by the 2000 GT roro ferry, this is done using MAXSURF Resistance software. The prisoner of this ship is calculated using Holtrop method. From the calculation, for full water vessel load when the full ship is $205.4 \mathrm{KN}$ and after the addition of wind resistance from wind turbines, the ship's resistance to being $207.4044 \mathrm{KN}$ [4].

Based on the calculation results can know the speed of new vessels to be $7.642094 \mathrm{~m} / \mathrm{s}$ or 14.85501 knots where there is a decrease of 0.144992 knots with the percentage decrease in vessel speed of $0.966615 \%$. But when comparing the results of the calculation of break horse power (BHP) when the maximum continuous rating (MCR) condition of the ship's main engine power at a speed of 15 knots service still has a power margin of $15.733 \%$. So that by utilizing the excess power, the ship can still run with the speed of his service for 15 knots.

Stability analysis on the 2000 GT pioneer vessel is done by simulating MAXSURF Stability software. To analyze the stability of the vessel, first create a load case table containing the type of equipment equipped with quantity, mass, and laying in longitudinal, transverse, and vertical on board. Based on the load case table, there will be a ship stability chart which, according to the graph, is the greatest return moment (GZ) is when the vessel forms an angle of $57.3^{\circ}$ the return moment (GZ) curve shown in Figure 5 [6][8][9].
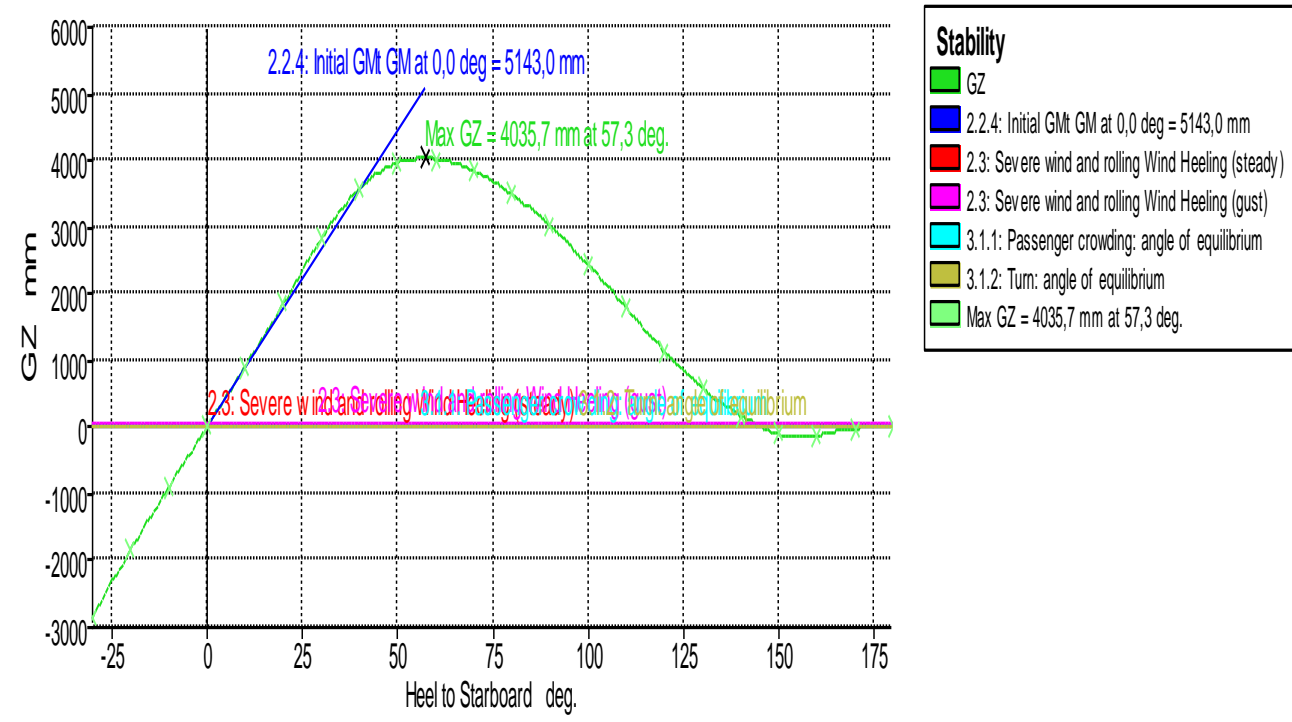

Figure 5. Return Moment (GZ)

\subsubsection{Fuel Saving Analysis}

Based on the reconfiguration of the electrical system on the 2000GT Pioneer vessel that has been done in the previous stage, we can then calculate the fuel savings we get from conventional electrical systems using generators with hybrid electrical systems using generators, solar panels, and wind turbines.

Fuel consumption for conventional systems is 1029300 liters/year with total operating fuel purchasing cost of $5.404 \mathrm{bn} /$ year and fuel consumption for hybrid system amounted to 848844 liters/year with total operating fuel purchasing cost of $4.456 \mathrm{bn} /$ year. The percentage of fuel savings that can be obtained by utilizing hybrid electrical systems using generators, solar panels, and wind turbines is $17.53 \%$. 


\subsection{Payload Calculation}

The payload is the maximum load that can be transported by ship. Payload becomes the main thing in commercial ship operations because the payload is a component that becomes income for ship owners and operators. With addition of wind turbines and solar panels, the vessel's payload is reduced.

To find out how economical this system is applied, it is necessary to calculate the reduced payload due to the addition of this mass. Total components of a hybrid system using wind turbines and solar panels are 17.22 tons and the weight difference of the generator after reconfiguring the ship's electrical system is 2,709 tons. The payload of vessels due to the addition of wind turbines and solar panels to 938.82 tons. The percentage reduction of vessel ship's payload due to the addition of wind turbines and solar panels is $1.564939 \%$.

\subsection{Break Even Point Calculation}

Break Even Point (BEP) is a condition where there do not experience losses and does not get a profit so that there is balance or break even. In the calculation of BEP, calculate the initial investment costs include wind turbines, solar panels, generators, inverters, battery chargers, etc. and calculate the operational and maintenance costs that include the cost of purchasing fuel, generator maintenance costs, wind turbine maintenance costs, solar panel maintenance costs, etc. Total investment, operational, and maintenance costs for conventional systems and hybrid systems are shown in the Table 10.

Table 10: Total Cost

\begin{tabular}{|l|c|c|}
\hline \multicolumn{1}{|c|}{ Cost } & Conventional System & Hybrid System \\
\hline Investment & $\operatorname{Rp~1.176.933.648,45~}$ & $\mathrm{Rp} \mathrm{4.473.221.879,52}$ \\
\hline Operational & $\operatorname{Rp~5.403.825.000,00}$ & $\mathrm{Rp} \mathrm{4.456.431.000,00}$ \\
\hline Maintenance & $\operatorname{Rp~549.275.675,13}$ & $\mathrm{Rp} \mathrm{630.667.478,44}$ \\
\hline Total & $\operatorname{Rp~7.130.034.323,58}$ & $\mathrm{Rp} \mathrm{9.560.320.357,96}$ \\
\hline
\end{tabular}

Figure 6 shows a BEP graph of a hybrid electrical system calculated over 10 years. Based on the graph it can be seen that the BEP will be achieved after 3 years 10 months the system is operating. Through the graph showed it can be concluded that with the time of the break-even point that can be achieved after this system operates for 3 years and 10 months then the system is feasible to use. Figure 7 shows the potential gains to be earn calculated over 10 years. 


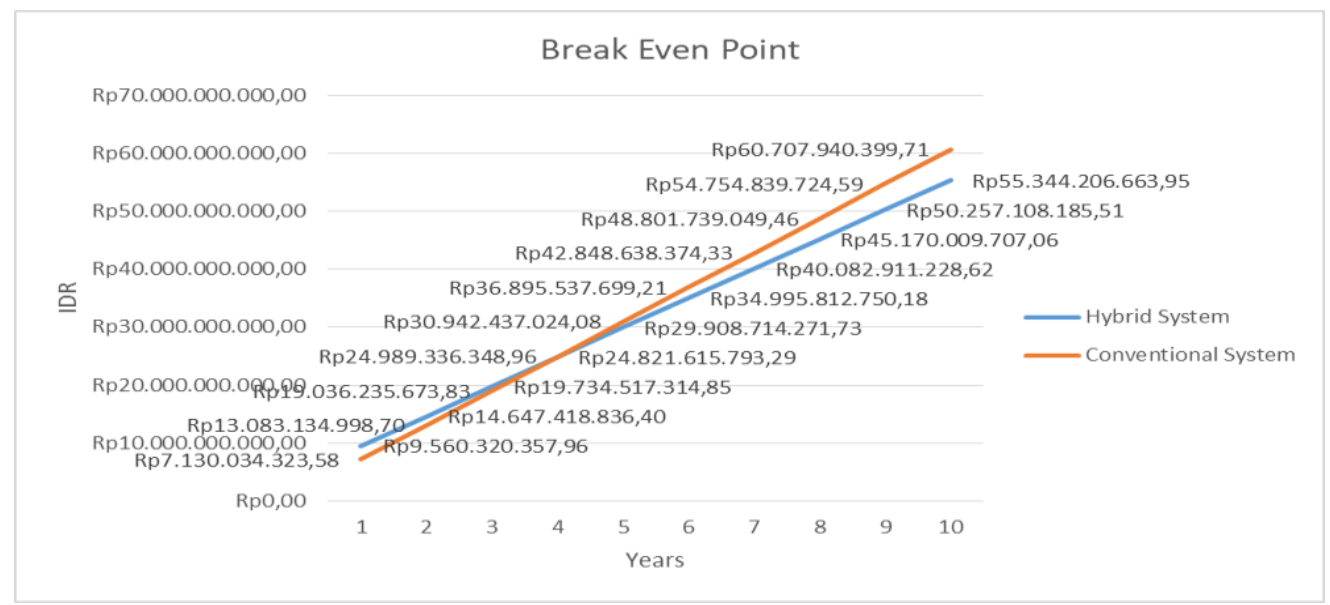

Figure 6: Break Even Point

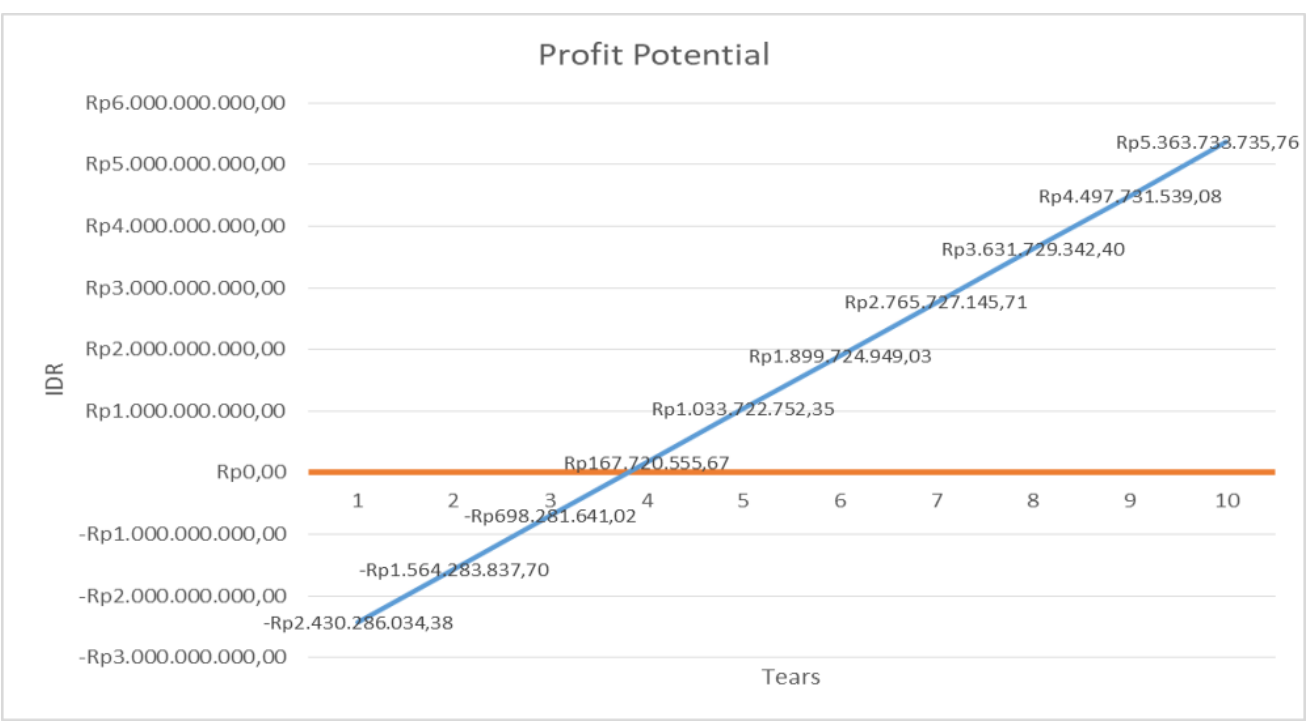

Figure 7: Profit Potential

\subsection{Bill of Quantity List}

Bill of Quantity of planned system to meet the electrical needs of lights on board the Pioneer 2000 GT is shown in Table 11.

Table 11: Bill of Quantity List

\begin{tabular}{|l|l|l|c|c|}
\hline No & \multicolumn{1}{|c|}{ Component } & \multicolumn{1}{|c|}{ Specification } & Total & Unit \\
\hline 1 & Solar Panel & $435 \mathrm{Wp}$ & 124 & Panel \\
\hline 2 & Wind Turbine & VAWT 3kW & 4 & Unit \\
\hline 3 & Wind Turbine & VAWT 10kW & 2 & Unit \\
\hline 4 & Battery & $12 \mathrm{~V}, 375 \mathrm{Ah}$ & 120 & Unit \\
\hline 5 & Solar Charger & Solar Charge Controller MPPT 48 V & 11 & Unit \\
\hline 6 & Wind Turbine Charger & MPPT 48 V & 3 & Unit \\
\hline 7 & Inverter & Inverter 48 V & 6 & Unit \\
\hline
\end{tabular}




\section{Conclusion}

Based on the results of technical and economic analysis that has been done above, it can be concluded that the use of solar panel systems and wind turbines to meet the needs of lighting in 2000 GT pioneer vessel is very possible because it can reduce fuel consumption by $17.53 \%$ per year and the period of break-even point balance points can be achieved in just 3 years and 10 months.

Total of solar panels with $435 \mathrm{Wp}$ nominal power that can be applied on board are 124 panels, a total wind turbine with nominal power $3 \mathrm{KW}$ that can be applied on the ship amounted are 4 pieces, and total wind turbine with nominal power $10 \mathrm{KW}$ that can be applied on board amounted are 2 pieces.

From the results of the technical analysis, the entire solar panel can generate power of $55.68 \mathrm{~kW}$ and overall wind turbine can generate power of $17.42 \mathrm{~kW}$. With the reduction of generator power, the consumption of fuel oil are reduce.

\section{References}

[1] Y. Rivaldhi and A. Nasirudin, "Economical And Technical Analysis Of Wind Turbine Installation On 6500 DWT Tanker Ship As Lighting System Power Source," ITS Online Publication, p. 10, 2012.

[2] D. N. Nugroho, Analysis of Battery Charging in The Design of A Savonius Type Vertical Axis Wind Turbine for Electrical Loads, Depok: Indonesia University, 2011.

[3] E. Bockmann and S. Steen, "Wind Turbine Propulsion of Ships," Second International Symposium on Marine Propulsors, p. 10, 2011.

[4] G. A. Rizkyan, S. Sarwito and M. B. Zaman, "Study of Ocean Wind Power Plant for Lighting Load on Suramadu Bridge, "ITS Online Publication, 2010.

[5] G. J. Jacobs, Small Wind Turbine Systems For Battery Charging, Veldhoven, 2003.

[6] E. V. Lewis, Principal of Naval Architecture - Resistance, Propulsion, and Vibration, Society of Naval Architects and Marine Engineers, 2004.

[7] E. H. Lysen, Introduction to Wind Energy, Amersfoort: CWD, 1983.

[8] B. Barrass and D. R. Derrett, Ship Stability for Masters and Mates, Oxford: Butterworth-Heinemann, 2012.

[9] Y. Purwanto, B. H. Iskandar, M. Imron and B. Wiryawan, "Safety Aspects Pole and Liner From Ship Stability and Regulation Point of View in Bitung, North Sulawesi," Marine Fisheries, 2014. 